\title{
Optimasi Kombinasi Biaya Bahan Bakar dan Emisi Pembangkit Energi Listrik menggunakan Teknik Reduksi Tempat Kedudukan
}

\author{
JANGKUNG RAHARJO
}

\author{
Fakultas Teknik Elektro, Universitas Telkom \\ Email: jangkungraharjo@telkomuniversity.ac.id
}

Received 18 Januari 2021 | Revised 2 Februari 2021 | Accepted 19 Februari 2021

\begin{abstract}
ABSTRAK
Dalam pengoperasian pembangkit energi listrik bukan saja untuk mendapatkan biaya yang minimal, namun juga meminimalkan emisi yang dihasilkan atau dikenal dengan Combined Economic Emission Dispatch (CEED), karena emisi merupakan bagian dari permasalahan energi. Makalah ini mengusulkan teknik reduksi tempat kedudukan untuk memecahkan masalah CEED. Prinsip dasar dari teknik ini adalah menebarkan sejumlah kandidat pada tempat kedudukan, $S^{0}$ yang dibentuk dari limit daya generator, dan ditentukan sebuah kandidat terbaik. $S^{0}$ diperkecil dan proses diulangi hingga didapatkan tempat kedudukan yang sangat kecil dimana kandidat terbaiknya dapat dianggap sebagai titik optimal. Teknik ini lebih akurat dibandingkan dengan metoda lain seperti Gradient Method (GM), Ant Colony Optimization (ACO), Particle Swarm Optimization (PSO), JAYA Algorithm dan Whale Optimization Algorithm (WOA). Hasilnya memberikan penghematan biaya tanpa melibatkan emisi masing-masing terhadap GM, ACO, PSO, WOA dan JAYA sebesar 9,24\%, 3,91\%, 0,56\%, 0,47\% dan 0,21\%, serta bila melibatkan emisi sebesar $21,28 \%, 16,09 \%, 5,52 \%, 5,31 \%$ dan $5,04 \%$.
\end{abstract}

Kata kunci: CEED, reduksi tempat kedudukan, penghematan biaya, optimal, akurat.

\begin{abstract}
In an operating, generator units not only to get minimal costs but also to consider the emissions produced, known as the Combined Economic Emission Dispatch (CEED), because emission is part of the energy problem. This paper proposes a feasible area reduction technique for solving CEED problems. The basic principle of this technique is to spread number of candidates on a feasible area, $S^{0}$ which is formed by generator limits from $n$ generator units and the best candidate is determined. $S^{0}$ is reduced and the process is repeated until a very small area is found, where the best candidate can be considered the solution. This technique is more accurate than other methods such as GM, ACO, PSO, JAYA Algorithm and WOA. The result provides cost savings without involving emission of GM, ACO, PSO, WOA and JAYA of $9.24 \%, 3.91 \%, 0.56 \%, 0.47 \%$ and $0.21 \%$ respectively, as well as when it involves emissions amounted to $21.28 \%, 16.09 \%, 5.52 \%, 5.31 \%$ and $5.04 \%$ respectively.
\end{abstract}

Keywords: CEED, feasible area reduction, cost saving, optimal, accurate 
Optimasi Kombinasi Biaya Bahan Bakar dan Emisi Pembangkit Energi Listrik menggunakan

Teknik Reduksi Tempat Kedudukan

\section{PENDAHULUAN}

Kebutuhan energi listrik dalam kehidupan semakin meningkat dari waktu ke waktu, dimana sebagian besar sumber energi listrik masih berupa sumber energi fosil yang tentunya di dalam pengoperasiannya menghasilkan emisi gas buang yang berbahaya. Pengoperasian pembangkit energi listrik berbahan bakar dari fosil memberikan dampak emisi yang membahayakan lingkungan (Güvenç, Sönmez, Duman, \& Yörükeren, 2012). Berbagai upaya untuk menjaga lingkungan telah dilakukan, baik berupa kebijakan nasional (seperti kebijakan Kementerian Lingkungan Hidup), kebijakan internasional (seperti Protokol Kyoto), maupun berbagai penelitian untuk menekan atau mengoptimasi emisi gas buang yang dihasilkan dari operasi pembangkit energi listrik berbahan bakar fosil tersebut. Masalah optimasi emisi gas buang ini merupakan salah satu masalah bidang energi yang harus dipecahkan. Sehingga penelitian terkait optimasi biaya pembangkitan energi listrik saat ini bukan hanya untuk mendapatkan biaya pembangkitan energi listrik yang murah saja, namun juga melibatkan optimasi emisi yang dihasilkan oleh pembangkitan energi listrik tersebut. Untuk alasan tersebut saat ini pengoperasian unit-unit generator bukan saja untuk mendapatkan biaya yang murah khususnya biaya bahan bakar yang disebut dengan masalah Economic Dispatch (ED), tetapi juga meminimalkan emisi yang dihasilkan atau dikenal dengan Economic Emission Dispatch (EED) atau Combined Economic Emission Dispatch (CEED) (Bhattacharya \& Chattopadhyay, 2011). Beberapa metoda untuk memecahkan masalah EED telah dipublikasikan, baik metoda numerik seperti Gradient Method (GM), Dynamic programming (DP), Direct Method (DM), Lambda Iteration (LI) dan Lagrange Method (LM) maupun metoda artifisial seperti Metoda Artificial Neural Network (ANN), Particle Swarm Optimization (PSO), Genetic Algorithm (GA), Flower Pollination Algorithm (FPA), Whale Optimization Algorithm (WOA), Bat Algorithm (BA), Simulated Annealing Algorithm (SAA), JAYA Algorithm, Firefly Algorithm (FA), Gravitational Search Algorithm (GSA), Artificial bee Colony (ABC) dan sebagainyam (Rao, 2016), (Kar, Dash, \& Sanyal, 2019).

Pemecahan masalah EED menggunakan metoda FA telah dipublikasikan (Apostolopoulos \& Vlachos, 2010) yang hasilnya dibandingkan dengan metoda PSO, dimana dalam penelitian tersebut secara umum FA memberikan kinerja lebih bagus dibanding PSO, baik dalam hal biaya bahan bakar, rugi-rugi daya maupun emisinya. Metoda GSA untuk pemecahan EED telah dipublikasikan oleh (Güvenç, Sönmez, Duman, \& Yörükeren, 2012), dan dibandingkan hasilnya dengan metoda $\gamma$-iteration, Recursive, PSO, DE, Simplified Recursive dan GA. GSA memberikan hasil yang paling baik, ditunjukkan dengan biaya dan emisi yang didapatkan paling rendah dibanding dengan metoda lainnya untuk berbagai daya beban.

Sedangkan (Adhirai, Mahapatra, \& Singh, 2018) mempublikasikan metoda WOA, dan menunjukkan metoda ini efektif untuk iterasi yang besar dan menunjukkan hasil yang tidak konsisten untuk iterasi di bawah 500. Sementara itu (Faseela \& Vennila, 2018) membandingkan metoda WOA dengan PSO yang diuji dengan sistem IEEE-30 bus. Hasilnya menunjukkan bahwa WOA lebih unggul dari PSO, dimana biaya bahan bakar dan emisi yang dihasilkan dengan metoda WOA lebih kecil dibanding PSO. Perbandingan metoda WOA dengan metoda PSO, DE, SOS, dan GWO dalam memecahkan masalah EED pada sistem microgrid dengan melibatkan sumber energi terbarukan dipublikasikan oleh (Dey, Roy, \& Bhattacharyya, 2019), yang memberikan kesimpulan keunggulan WOA dibanding metoda pembandingnya. Sementara (Kar, Dash, \& Sanyal, 2019) menerapkan WOA dalam pemecahan masalah EED pada sistem tenaga hibrid yang terdiri dari hidro, angin dan termal. Dibandingkan dengan metoda RCGA, NSGA-II dan SPEA-2, maka WOA memberikan hasil terbaik, baik dilihat dari biaya bahan bakar, emisi yang dikeluarkan maupun waktu proses. 
Perbandingan metoda artifisial dan metoda numerik dalam memecahkan EED dipublikasikan oleh (Maydilasari, Zuliari, \& Wati, 2020) dimana PSO sebagai metoda artifisial dan Lagrange sebagai metoda numerik. Hasilnya menunjukkan bahwa biaya dari metoda PSO lebih rendah dibanding LM, baik untuk EED tanpa mempertimbangkan Valve-Point Effect (VPE) maupun ketika mempertimbangkan VPE. Sementara itu metoda Gravitational Particle Swarm Optimization Algorithm (GPSOA) untuk memecahkan masalah EED pada sistem tenaga hibrid antara tenaga angin dan tenaga termal, dan memberikan hasil terbaik bila dibandingkan dengan metoda GA, PSO, GSA, dan PSOGSA, baik dari sisi biaya bahan bakar maupun emisi yang dikeluarkan (Jiang, Zhang, Wu, \& Chen, 2019).

Pengujian metoda Weighting update Artificial Bee Colony (WU-ABC) pada sistem microgrid yang terhubung ke jaringan yang dimodifikasi dan dibandingkan dengan metoda artifisial lainnya, yaitu ABC, IML-ABC, WU-GA, dan WU-PSO dilakukan oleh (Ryu \& Kim, 2020). Dilihat dari biaya bahan bakar, emisi yang dihasilkan dan waktu proses, maka WU-ABC memberikan kinerja terbaik.

Pemecahan masalah EED pada sistem tenaga termasuk sumber energi terbarukan telah distudi oleh (Dhifaoui, Marouani, \& Abdallah, 2020), dimana metoda artifisial the multi objective ant lion optimizer (MOALO) digunakan untuk keperluan tersebut dan dibandingkan dengan berbagai metoda artifisial lainnya yaitu PSO, DE-SQP, PSO-SQP, MODE, MOHDE-SAT, NPAHS, $\mathrm{EP}, \mathrm{SA}, \mathrm{PS}$, dan NEHS. Pada pengujian ini dilakukan tanpa melibatkan ramp rate dan dengan melibatkan ramp rate. Secara keseluruhan dapat dikatakan metoda MOALO memiliki kinerja terbaik dibandingkan metoda pembandingnya.

Hampir semua metoda yang dikemukakan adalah metoda artifisial. Metoda-metoda tersebut sangat komplek karena banyak parameter yang dikontrol secara akurat. Akurasi dari metoda artifisial tergantung pada pengontrolan panjang langkah (step) dan jumlah populasi. Belum ada penelitian tentang pengontrolan panjang langkah dan jumlah populasi untuk mendapatkan hasil yang akurat.

Metode artifisial yang lebih sederhana adalah Reduksi Tempat Kedudukan (RTK) kandidat. Teknik ini memiliki pendekatan yang berbeda dengan metode artifisial lainnya, dimana teknik ini tidak lagi menggunakan pendekatan titik-ke-titik untuk mencapai titik solusi, tetapi menggunakan pendekatan area-ke-area (atau dari tempat kedudukan ke tempat kedudukan yang lebih kecil). Area yang layak (feasible area) sebagai tempat kedudukan kandidat diperkecil hingga yang terkecil sehingga merepresentasikan sebuah titik yang disebut titik solusi. Oleh karena itu, metode ini tidak dibatasi oleh bentuk-bentuk fungsi tujuan, baik yang dapat diturunkan (differentiable) maupun tidak.

Tujuan utama penelitian ini adalah melakukan optimasi kombinasi biaya bahan bakar dan emisi pembangkit energi listrik menggunakan teknik RTK. Untuk melihat kinerja dari teknik yang diusulkan, khususnya keakuratannya, maka teknik ini diuji dengan beban harian pada sistem microgrid yang terdiri dari unit pembangkit energi angin, unit pembangkit energi surya, dan pembangkit energi konvensional. Hasil dari Teknik RTK divalidasi dengan cara dibandingkan dengan metoda lain, baik metoda konvensional (GM) maupun sesama metoda artifisial (ACO, PSO, WOA, dan JAYA).

Makalah ini terdiri dari empat bagian utama. Bagian pertama menjelaskan metodologi penelitian yang menjelaskan formulasi masalah dan prinsip kerja serta algoritma teknik RTK yang diusulkan. Bagian kedua menampilkan tentang data dan hasil pengujian sistem. Bagian ketiga membahas hasil yang didapat dan dibandingkan dengan hasil dari metoda lain yang sudah popular lebih dulu. Bagian terakhir menyampaikan kesimpulan. 


\section{METODOLOGI PENELITIAN}

\subsection{Formulasi masalah}

Pembahasan mengenai pembangkit energi, khususnya pembangkit energi yang menggunakan bahan bakar fosil tidak bisa dipisahkan dari masalah emisi yang dihasilkan, karena masalah penanganan emisi adalah bagian dari masalah energi (Gonidakis \& Vlachos, 2015). Saat ini emisi menjadi topik hangat karena masyarakat telah menyadari betapa pentingnya emisi sebagai perusak bumi. Sehingga tujuan utama dari pengiriman daya adalah mengurangi total biaya bahan bakar pembangkit dan mengurangi tingkat emisi sistem secara bersamaan tanpa melanggar batasan sistem (Güvenç, Sönmez, Duman, \& Yörükeren, 2012) dalam memenuhi permintaan beban. Sehingga dalam pembangkitan energi listrik pada sistem microgrid yang terdiri dari pembangkit berbahan bakar fosil dan pembangkit energi terbarukan seperti pembangkit energi angin dan pembangkit energi surya, perlu dikemukakan formulasi biaya bahan bakar dan nilai emisi, perkiraan pembangkitan energi angin dan surya serta fungsi-fungsi pembatas generator. Fungsi biaya bahan bakar generator dituliskan sebagai Persamaan kuadratik sebagai berikut (Wood, Wollenberg, \& Sheblé, 2013):

$$
\begin{gathered}
\text { TEC }=\sum_{i=1}^{n} F_{i} \\
\breve{P}_{i} \leq P_{i} \leq \hat{P}_{i}, i=1,2, \ldots, n
\end{gathered}
$$

Asumsi rugi-rugi saluran diabaikan maka berlaku Persamaan (3).

$$
\sum_{i=1}^{n} P_{i}-P_{D}=0
$$

dengan $T C$ adalah biaya total, $\mathrm{n}$ adalah jumlah generator, $P$ adalah daya keluaran generator, $P_{D}$ adalah beban, $\check{P}$ adalah batas daya minimum dan $\hat{P}$ adalah batas daya maksimum. Sedangkan biaya bahan bakar pembangkitan energi $F_{i}$ sebagai fungsi daya yang dibangkitkan, ditunjukkan pada Persamaan (4) dan (5) (Wood, Wollenberg, \& Sheblé, 2013).

$$
\begin{gathered}
F_{i}=f_{i}\left(P_{i}\right) \\
F_{i}=a_{i}\left(P_{i}\right)^{2}+b_{i}\left(P_{i}\right)+c_{i}
\end{gathered}
$$

Fungsi emisi juga diformulasikan sebagai fungsi kuadrat sebagai berikut:

$$
\begin{gathered}
T E M=\sum_{i=1}^{n} E_{i} \\
E_{i}=u_{i}\left(P_{i}\right)^{2}+v_{i}\left(P_{i}\right)+w_{i}
\end{gathered}
$$

Dari Persamaan (1) dan (6), didapatkan total biaya EED, yang dituliskan sebagai berikut (Hardiansyah, Junaidi, \& Yandri, 2016):

$$
\begin{gathered}
T C=\sum_{i=1}^{n} F_{i}+\sum_{i=1}^{n} E_{i} \\
T C=\sum_{i=1}^{n}\left[\left(a_{i} P_{i}^{2}+b_{i} P_{i}+c_{i}\right)+x_{i}\left(u_{i} P_{i}^{2}+v_{i} P_{i}+w_{i}\right)\right]
\end{gathered}
$$

Sehingga tujuan dari EED ini adalah meminimalkan Persamaan (9). TC adalah total biaya pada CEED; $a_{i}$ adalah koefisien biaya generator ke- $i$, dalam $\left[\$ / \mathrm{MW}^{2} \mathrm{~h}\right] ; b_{i}$ adalah koefisien biaya generator ke-i, dalam $[\$ / \mathrm{MWh}] ; c_{i}$ adalah koefisien biaya generator ke- $i$, dalam $[\$ / \mathrm{h}] ; u_{i}$ adalah koefisien emisi generator ke-i, dalam $\left[\mathrm{kg} / \mathrm{MW}^{2} \mathrm{~h}\right] ; v_{i}$ adalah koefisien emisi generator ke- $i$, dalam $[\mathrm{kg} / \mathrm{MWh}]$; dan $w_{i}$ adalah koefisien emisi generator ke- $i$, dalam $[\mathrm{kg} / \mathrm{h}]$. TEC adalah 
total biaya bahan bakar; TEM adalah total nilai emisi. Sedangkan $x_{i}$, adalah harga faktor penalti (price penalty factor), dalam $[\$ / \mathrm{kg}]$ yang berarti suatu ukuran untuk mentransformasi dari massa emisi ke biaya bahan bakar untuk emisi tersebut (Bhesdadiya, et al., 2016), yang diformulasikan dalam Persamaan (10) (Hardiansyah, Junaidi, \& Yandri, 2016).

$$
x_{i}=\frac{\left(a_{i} P_{i, \min }^{2}+b_{i} P_{i, \min }+c_{i}\right)}{\left(u_{i} P_{i, \max }^{2}+v_{i} P_{i, \max }+w_{i}\right)}
$$

dengan $P_{i, \min }$ dan $P_{i, \max }$ adalah masing-masing daya minimum dan daya maksimum yang dibangkitkan generator ke- $i$.

\subsection{Teknik Reduksi Tempat Kedudukan}

Metoda yang diusulkan pada makalah ini adalah Teknik Reduksi Tempat Kedudukan (RTK). Teknik RTK ini termasuk dalam metoda artifisial, namun di dalam mencapai titik optimal (solusi) tidak seperti metoda artifisial pada umumnya yang menggunakan pendekatan titik ke titik. Teknik RTK ini menggunakan pendekatan tempat kedudukan ke tempat kedudukan atau area ke area dalam mencapai titik optimal, sehingga tidak akan jatuh pada titik minimum global seperti yang sering terjadi pada metoda PSO (Li, Du, \& Nian, 2014). Hal itu merupakan keunikan sekaligus keunggulan dari teknik RTK. Sehingga metode yang diusulkan ini adalah metode iterasi melalui solusi tempat kedudukan kandidat ke tempat kedudukan kandidat yang lebih kecil. Kandidat solusi ditebar pada tempat kedudukan dan ditentukan kandidat yang terbaik, yaitu kandidat yang memiliki TC terendah. Tempat kedudukan diperkecil dan ditebar sejumlah kandidat yang sama sehingga kerapatan kandidat pada tempat kedudukan ini menjadi lebih tinggi, dan ditentukan kandidat yang terbaik lagi. Proses diulang hingga sampai pada tempat kedudukan yang sangat kecil dimana kandidat terbaiknya dapat dianggap sebagai titik solusi (optimum) dan iterasi berhenti. Iterasi berhenti apabila selisih antara TC pada iterasi ke $\mathrm{t}$ dan TC pada iterasi ke $t-1$ sudah tidak signifikan, seperti ditunjukkan pada Persamaan (11).

$$
\delta=T C^{t}-T C^{t-1} \leq \varnothing
$$

dengan $\delta$ adalah selisih harga antara TC pada iterasi ke t dan TC pada iterasi ke t-1, $\emptyset$ adalah suatu nilai yang sangat kecil dibandingkan TC. Semakin kecil $\varnothing$ tentunya akan memberikan hasil semakin akurat, namun hal ini akan diikuti dengan iterasi yang semakin banyak.

Prinsip dasar teknik RTK secara sederhana ditunjukkan pada Gambar 1. Tempat kedudukan kandidat dibentuk dari batasan daya generator yang ada. Untuk dua buah generator maka tempat kedudukan berupa garis, sedangkan untuk tiga buah generator, maka tempat kedudukan berupa bidang, untuk empat generator maka tempat kedudukan berupa ruang, dan seterusnya. Sebagai contoh sederhana, diambil dua buah generator dengan tempat kedudukan kandidat ditunjukkan sepanjang garis $\overline{A B}$, yang disebut $\mathrm{S}^{0}$, pada Gambar 1 . Pada $\mathrm{S}^{0}$, ditebar kandidat sebanyak tujuh buah secara merata dan ditentukan kandidat terbaiknya, misal $\mathrm{P}^{\mathrm{b}(0)}$. Kemudian tempat kedudukan diperkecil menjadi $\mathrm{S}^{1}$, dan $\mathrm{P}^{\mathrm{b}(0)}$ berada di tengah $\mathrm{S}^{1}$. Pada kondisi ini disebut iterasi pertama. Pada tempat kedudukan $\mathrm{S}^{1}$, yaitu sepanjang garis $\overline{C E}$, ditebar kembali tujuh buah kandidat. Pada $S^{1}$ ini terdapat sebuah kandidat yang berada di luar $\mathrm{S}^{0}$, yaitu kandidat pada titik $\mathrm{E}$. Kandidat ini disebut kandidat gagal dan dihapus pada iterasi ini, atau dengan kata lain tidak dilibatkan dalam penentuan kandidat terbaik, walaupan kandidat tersebut masih terletak pada tempat kedudukan $\mathrm{S}^{1}$ (tetapi berada di luar $\mathrm{S}^{0}$, sehingga melanggar batasan generator). Dengan demikian, kandidat terbaik pada iterasi pertama ini ditentukan dari kandidat-kandidat yang berada pada garis $\overline{C D}$, misal didapat kandidat terbaik $\mathrm{P}^{\mathrm{b}(1)}$. Tempat kedudukan diperkecil lagi dengan $\mathrm{P}^{\mathrm{b}(1)}$ berada ditengah tempat kedudukan yang 
baru, dan proses berulang hingga didapatkan kondisi dimana Persamaan (11) terpenuhi, yaitu total biaya (TC) pada iterasi ke t dengan TC pada iterasi ke t-1 sudah tidak begitu signifikan. Pada makalah ini, nilai $\varnothing$ pada Persamaan (9) ditetapkan sebesar $\$ 0.5$.

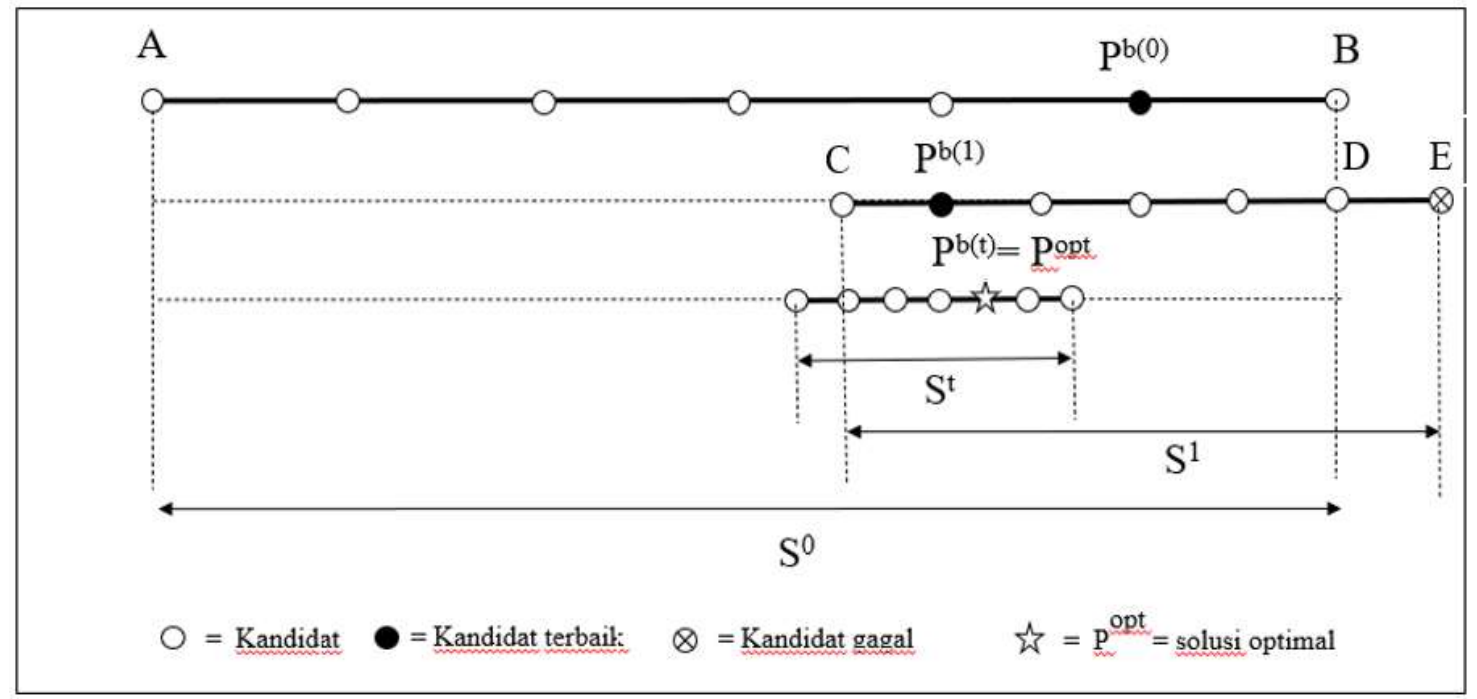

\section{Gambar 1. Teknik Reduksi Tempat Kedudukan}

Teknik yang diusulkan disimulasikan menggunakan MATLAB. Adapun prosedur langkah demi langkah ditunjukkan pada Tabel 1 dan diagram alir ditunjukkan pada Gambar 2.

Tabel 1. Algoritma dari Teknik RTK

\begin{tabular}{|r|l|}
\hline 1 & Masukkan data. \\
\hline 2 & Tentukan tempat kedudukan kandidat (sebut $\mathrm{S}^{0}$ ), yang disusun dari kendala generator. \\
\hline 3 & Sebarkan sejumlah kandidat, $\mathrm{N}$. \\
\hline 4 & Hitung TC untuk setiap kandidat melalui Persamaan $(9)$. \\
\hline 5 & $\begin{array}{l}\text { Perkecil tempat kedudukan kandidat (sebut } \mathrm{S}^{1} \text { ), dengan kandidat terbaik pada } \mathrm{S}^{0} \text { berada di } \\
\text { tengah-tengah } \mathrm{S}^{1} \text {. }\end{array}$ \\
\hline 6 & Tebar kembali sejumlah N kandidat pada $\mathrm{S}^{1}$. \\
\hline 7 & Hilangkan kandidat yang berada di luar $\mathrm{S}^{0}$. \\
\hline 8 & Hitung $\delta$, menggunakan Persamaan (11). \\
\hline 9 & $\begin{array}{l}\text { Jika } \delta \leq \emptyset, \text { maka titik solusi didapatkan, lanjut ke Langkah } 12 . \text { Jika } \delta \geq \emptyset \text {, maka tentukan tempat } \\
\text { kedudukan yang baru (yang lebih kecil dari sebelumnya). }\end{array}$ \\
\hline 10 & Tentukan kandidat terbaik \\
\hline 11 & Lanjut ke Langkah 4. \\
\hline 12 & Hasil. \\
\hline 13 & Selesai. \\
\hline
\end{tabular}

Gambar 2 menjelaskan bahwa pengujian dilakukan dengan beban harian, sehingga pada setiap jam harus dipastikan bahwa daya yang dibangkitkan telah mencapai titik optimal sebelum dilanjutkan ke jam berikutnya. Adapun pada pengujian tiap jam diawali dengan memasukkan data yaitu daya pembangkitan dari sumber energi surya ( $\left.P_{\text {surya }}\right)$ dan sumber energi angin $\left(P_{\text {angin }}\right)$ pada jam tersebut, batas daya maksimum dan minimum generator, serta fungsi biaya generator. 


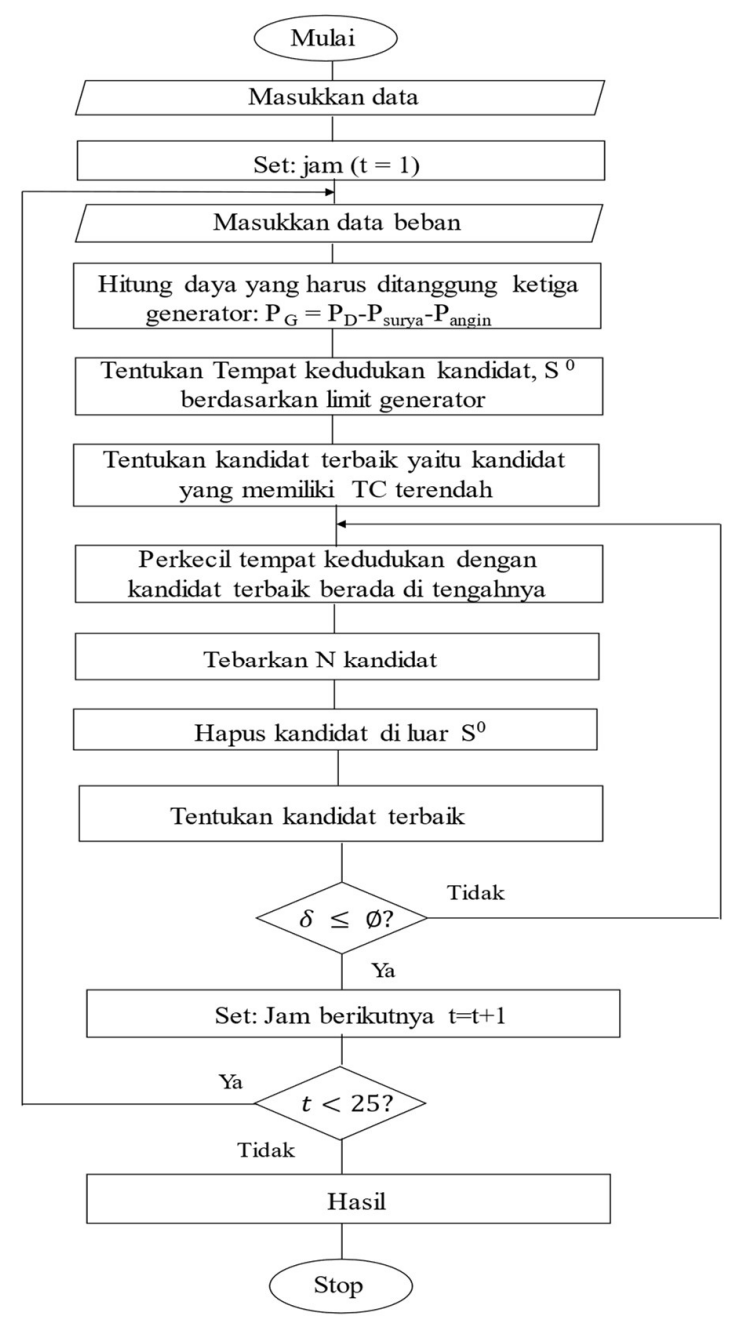

Gambar 2. Diagram Alir dari Teknik RTK

Dari $\mathrm{P}_{\text {surya, }} \mathrm{P}_{\text {angin, }}$ dan beban dapat diketahui daya yang harus ditanggung oleh ketiga generator. Dari batas maksimum dan batas minimum setiap generator dapat ditentukan tempat kedudukan untuk menebar kandidat solusi. Gabungan fungsi biaya bahan bakar (TEC) dan fungsi emisi (TEM) digunakan untuk menguji setiap kandidat pada setiap iterasi. Apabila $\delta$ yaitu selisih antara kandidat terbaik pada suatu iterasi dengan kandidat terbaik pada iterasi sebelumnya masih signifikan maka iterasi dilanjutkan hingga didapat harga $\delta$ yang lebih kecil atau sama dengan suatu harga yang telah diset $(\varnothing)$. Sedangkan bila $\delta$ sudah tidak signifikan, maka titik optimum (solusi) pada jam tersebut telah didapat, dan proses dilanjutkan ke jam berikutnya, hingga jam ke-24.

\section{HASIL DAN PEMBAHASAN}

Data yang digunakan dalam simulasi diberikan pada Tabel 2 hingga Tabel 5. Tabel 2 memuat tentang pembangkitan tenaga surya, yang diambil pada sistem microgrid (Bhoye, et al., 2016). Tabel 3 memuat tentang pembangkitan tenaga angin, yang juga diambil pada sistem microgrid (Bhoye, et al., 2016). Tabel 4 memuat karakteristik Generator yaitu batas maksimum dan batas minimum daya yang bisa dibangkitkan oleh masing-masing generator serta koefisien biaya ( $a, b$, dan $c)$, dimana fungsi biaya (karakteristik generator) diformulasikan 
dengan fungsi kuadrat (Wood, Wollenberg, \& Sheblé, 2013). Tabel 5 berisi data beban harian yang harus dilayani oleh kelima pembangkit yaitu pembangkit tenaga surya, pembangkit tenaga angin dan ketiga generator pembangkit konvensional (Wood, Wollenberg, \& Sheblé, 2013). Beban harian (Bhoye, et al., 2016) digunakan untuk menguji sistem.

Tabel 2. Pembangkitan Tenaga Surya

\begin{tabular}{|c|c|c|c|c|c|c|c|}
\hline Jam & $\begin{array}{c}\text { Pembangkitan } \\
\text { Tenaga Surya } \\
\text { (MW) }\end{array}$ & Jam & $\begin{array}{c}\text { Pembangkitan } \\
\text { Tenaga Surya } \\
\text { (MW) }\end{array}$ & Jam & $\begin{array}{c}\text { Pembangkitan } \\
\text { Tenaga Surya } \\
\text { (MW) }\end{array}$ & Jam & $\begin{array}{c}\text { Pembangkitan } \\
\text { Tenaga Surya } \\
\text { (MW) }\end{array}$ \\
\hline 1 & 0,00 & 7 & 6,27 & 13 & 31,94 & 19 & 0,00 \\
\hline 2 & 0,00 & 8 & 16,18 & 14 & 26,81 & 20 & 0,00 \\
\hline 3 & 0,00 & 9 & 24,05 & 15 & 10,08 & 21 & 0,00 \\
\hline 4 & 0,00 & 10 & 39,37 & 16 & 5,30 & 22 & 0,00 \\
\hline 5 & 0,00 & 11 & 7,41 & 17 & 9,57 & 23 & 0,00 \\
\hline 6 & 0,03 & 12 & 3,65 & 18 & 2,31 & 24 & 0,00 \\
\hline
\end{tabular}

Tabel 3. Pembangkitan Tenaga Angin

\begin{tabular}{|c|c|c|c|c|c|c|c|}
\hline Jam & $\begin{array}{c}\text { Pembangkitan } \\
\text { Tenaga Angin, } \\
\text { Pangin (MW) }\end{array}$ & Jam & $\begin{array}{c}\text { Pembangkitan } \\
\text { Tenaga Angin, } \\
\text { Pangin (MW) }\end{array}$ & Jam & $\begin{array}{c}\text { Pembangkitan } \\
\text { Tenaga Angin, } \\
\text { Pangin (MW) }\end{array}$ & Jam & $\begin{array}{c}\text { Pembangkitan } \\
\text { Tenaga Angin, } \\
\text { Pangin (MW) }\end{array}$ \\
\hline 1 & 1,70 & 7 & 14,66 & 13 & 14,35 & 19 & 0,75 \\
\hline 2 & 8,50 & 8 & 26,56 & 14 & 10,35 & 20 & 0,17 \\
\hline 3 & 9,27 & 9 & 20,58 & 15 & 8,26 & 21 & 0,15 \\
\hline 4 & 16,66 & 10 & 17,85 & 16 & 13,71 & 22 & 0,31 \\
\hline 5 & 7,22 & 11 & 12,80 & 17 & 3,44 & 23 & 1,07 \\
\hline 6 & 4,91 & 12 & 18.65 & 18 & 1,87 & 24 & 0,58 \\
\hline
\end{tabular}

Tabel 4. Karakteristik Generator

\begin{tabular}{|c|c|c|c|c|c|c|c|c|}
\hline Gen & $\begin{array}{c}P_{\min } \\
(\mathbf{M W})\end{array}$ & $\begin{array}{l}P_{\max } \\
(\mathrm{MW})\end{array}$ & $\begin{array}{c}a \\
\left(\$ / M W^{2} h\right)\end{array}$ & $\begin{array}{c}\mathbf{b} \\
(\$ / M W h)\end{array}$ & $\begin{array}{c}c \\
(\$ / h)\end{array}$ & $\begin{array}{c}\mathbf{d} \\
\left(\mathrm{kg} / \mathrm{M} \mathbf{W}^{2} \mathrm{~h}\right)\end{array}$ & $\begin{array}{c}\mathrm{e} \\
(\mathrm{kg} / \mathrm{MWh})\end{array}$ & $\begin{array}{c}f \\
(\mathbf{k g} / \mathrm{h})\end{array}$ \\
\hline G-1 & 37 & 150 & 0,024 & 21,000 & 1530,0 & 0,0105 & $-1,455$ & 60 \\
\hline G-2 & 40 & 160 & 0,029 & 20,160 & 992,0 & 0,0080 & $-0,600$ & 45 \\
\hline G-3 & 50 & 190 & 0,021 & 20,400 & 600,0 & 0,0120 & $-0,555$ & 30 \\
\hline
\end{tabular}

Tabel 5. Beban Harian

\begin{tabular}{|c|c|c|c|c|c|c|c|}
\hline Jam & $\begin{array}{c}\text { Beban, Pd } \\
(\mathbf{M W})\end{array}$ & Jam & $\begin{array}{c}\text { Beban, Pd } \\
(\mathbf{M W})\end{array}$ & Jam & $\begin{array}{c}\text { Beban, } \mathbf{P D}_{\mathbf{D}} \\
\mathbf{( M W )}\end{array}$ & Jam & $\begin{array}{c}\text { Beban, } \mathbf{P D}_{\mathbf{D}} \\
\mathbf{( M W )}\end{array}$ \\
\hline 1 & 140 & 7 & 175 & 13 & 240 & 19 & 200 \\
\hline 2 & 150 & 8 & 180 & 14 & 220 & 20 & 240 \\
\hline 3 & 155 & 9 & 210 & 15 & 200 & 21 & 225 \\
\hline 4 & 160 & 10 & 230 & 16 & 180 & 22 & 190 \\
\hline 5 & 265 & 11 & 240 & 17 & 170 & 23 & 160 \\
\hline 6 & 270 & 12 & 250 & 18 & 185 & 24 & 145 \\
\hline
\end{tabular}

Berdasarkan data beban yang diambil dari Tabel 5, data pembangkit energi surya yang diambil dari Tabel 2, data pembangkit energi angin yang diambil dari Tabel 3, maka dilakukan optimasi pembangkitan daya ketiga generator (G1, G2, dan G3) setiap jam. Dari data beban per jam dan data pembangkitan energi surya dan pembangkit energi angin per jam, dapat diketahui daya yang harus ditanggung oleh ketiga generator dan berapa daya yang ditanggung oleh masing-masing generator pada kondisi optimal. Kondisi optimal didapat dengan cara 
meminimisasi $F_{i}$ pada Persamaan (6) untuk optimasi biaya bahan bakar pembangkit energi tanpa mempertimbangkan emisi yang dikeluarkan (menyelesaikan masalah ED saja), dan meminimisasi TC pada Persamaan (10) untuk mengoptimasi kombinasi biaya bahan bakar dan Emisi Pembangkit Energi (EED).

Data yang digunakan untuk simulasi diambil dari (Bhoye, et al., 2016) dan (Trivedi, et al., 2016), agar dapat dibandingkan antara hasil metoda yang diusulkan (RTK) dengan metoda yang terlebih dahulu sudah dipublikasikan maka. Penelitian (Bhoye, et al., 2016) mengusulkan algoritma Jaya untuk menyelesaikan masalah EED, dan hasilnya dibandingkan dengan metoda GM, ACO, dan PSO. Pada waktu yang hampir bersamaan (Trivedi, et al., 2016) mengusulkan WOA untuk menyelesaikan masalah EED, dan hasilnya dibandingkan dengan metoda GM, ACO, dan PSO juga. Sementara makalah ini mengusulkan teknik RTK untuk menyelesaikan masalah CEED dan hasilnya dibandingkan dengan metoda GM, ACO, PSO, algoritma JAYA, dan WOA. Pada penyelesaian masalah EED dengan menggunakan teknik yang diusulkan, digunakan jumlah kandidat sebesar 250 buah dan $\varnothing$ diset sebesar $\$ 0.5$. Angka ini tentunya sangat tidak signifikan dibanding dengan TC yang didapat. Tabel 6 menunjukkan hasil simulasi dari teknik RTK dalam menyelesaikan masalah ED dan EED.

Tabel 6. Hasil Simulasi Teknik RTK

\begin{tabular}{|c|c|c|c|c|c|c|c|c|c|}
\hline \multirow{2}{*}{ Jam } & Beban & Surya & Angin & \multicolumn{2}{|c|}{$\begin{array}{c}\text { Pembangkitan Daya, } \\
\text { PG (MW) }\end{array}$} & $\begin{array}{c}\text { Total } \\
\text { Pembangkitan }\end{array}$ & ED & EED \\
\cline { 2 - 10 } & $\mathbf{( M W )}$ & $\mathbf{( M W )}$ & $\mathbf{( M W )}$ & $\mathbf{G 1}$ & $\mathbf{G 2}$ & $\mathbf{G 3}$ & $\mathbf{( M W )}$ & $\mathbf{( \$ / j a m )}$ & $\mathbf{( \$ / j a m )}$ \\
\hline 1 & 2 & 3 & 4 & 5 & 6 & 7 & 8 & 9 & 10 \\
\hline 1 & 140 & 0,00 & 1,70 & 37,00 & 44,20 & 57,10 & 140,00 & 6112,892 & 6912,060 \\
\hline 2 & 150 & 0,00 & 8,50 & 51,42 & 40,00 & 50,08 & 150,00 & 5952,557 & 6572,961 \\
\hline 3 & 155 & 0,00 & 9,27 & 55,73 & 40,00 & 50,00 & 155,00 & 6201,660 & 6796,890 \\
\hline 4 & 160 & 0,00 & 16,66 & 38,00 & 45,20 & 60,14 & 160,00 & 6227,945 & 7024,942 \\
\hline 5 & 165 & 0,00 & 7,22 & 63,00 & 44,00 & 50,78 & 165,00 & 6573,503 & 7151,303 \\
\hline 6 & 170 & 0,03 & 4,91 & 64,00 & 50,00 & 51,06 & 170,00 & 6741,178 & 7319,310 \\
\hline 7 & 175 & 6,27 & 14,66 & 62,00 & 41,03 & 51,04 & 175,00 & 6488,164 & 7067,844 \\
\hline 8 & 180 & 16,18 & 26,56 & 45,20 & 40,00 & 52,06 & 180,00 & 6091,972 & 6771,869 \\
\hline 9 & 210 & 24,05 & 20,58 & 64,27 & 50,00 & 51,00 & 209,90 & 6746,326 & 7324,215 \\
\hline 10 & 230 & 39,37 & 17,85 & 47,78 & 54,53 & 70,47 & 230,00 & 6907,602 & 7641,698 \\
\hline 11 & 240 & 7,41 & 12,80 & 74,00 & 68,09 & 77,70 & 240,00 & 8026,433 & 8751,528 \\
\hline 12 & 250 & 3,65 & 18,65 & 68,00 & 69,20 & 90,50 & 250,00 & 8213,114 & 9005,250 \\
\hline 13 & 240 & 31,94 & 14,35 & 69,50 & 59,21 & 65,00 & 240,00 & 7407,493 & 8046,690 \\
\hline 14 & 220 & 26,81 & 10,35 & 59,84 & 59,00 & 64,00 & 220,00 & 7169,694 & 7803,501 \\
\hline 15 & 200 & 10,08 & 8,26 & 48,30 & 57,81 & 75,55 & 200,00 & 7115,741 & 7873,742 \\
\hline 16 & 180 & 5,30 & 13,71 & 63,60 & 45,80 & 51,59 & 180,00 & 6606,077 & 7186,039 \\
\hline 17 & 170 & 9,57 & 3,44 & 55,70 & 44,05 & 57,24 & 170,00 & 6546,980 & 7167,122 \\
\hline 18 & 185 & 2,31 & 1,87 & 68,21 & 55,41 & 57,20 & 185,00 & 7107,765 & 7710,774 \\
\hline 19 & 200 & 0,00 & 0,75 & 56,07 & 66,10 & 77,08 & 200,00 & 7531,405 & 8247,883 \\
\hline 20 & 240 & 0,00 & 0,17 & 72,83 & 76,05 & 90,95 & 240,00 & 8508,713 & 9319,297 \\
\hline 21 & 225 & 0,00 & 0,15 & 61,09 & 74.42 & 89,34 & 225,00 & 8145,527 & 8928,892 \\
\hline 22 & 190 & 0,00 & 0,31 & 56,02 & 58,72 & 74,95 & 190,00 & 7304,474 & 8008,535 \\
\hline 23 & 160 & 0,00 & 1,07 & 57,81 & 48,87 & 52,25 & 160,00 & 6593,928 & 7187,706 \\
\hline 24 & 145 & 0,00 & 0,58 & 53,92 & 41,05 & 49,45 & 145,00 & 6244,009 & 6846,873 \\
\hline
\end{tabular}

Daya yang dihasilkan dari pembangkit surya dan pembangkit angin selama 24 jam seperti tertera pada Tabel 2 dan Tabel 3, bersama dengan daya yang dihasilkan oleh tiga pembangkit konvensional (Tabel 4) digunakan untuk melayani beban harian (Tabel 5). Agar dapat dibandingkan antara hasil simulasi menggunakan teknik RTK dengan metoda lain secara adil maka dibandingkan antara pembangkitan ketiga pembangkit konvensional pada metoda RTK 
dengan metoda pembanding yaitu metoda yang diusulkan oleh (Bhoye, et al., 2016) dan (Trivedi, et al., 2016), baik tanpa mempertimbangkan emisi (ED) maupun dengan mempertimbangkan emisi (EED).

Hasil simulasi dari teknik RTK dengan jumlah kandidat 250 dan $\varnothing$ diset sebesar $\$ 0,5$, menunjukkan bahwa besar daya yang dibangkitkan oleh kelima pembangkit selalu sama dengan beban (Tabel 6), dengan kata lain memenuhi Persamaan (3). Hal ini mengindikasikan bahwa teknik RTK yang diusulkan memiliki tingkat akurasi tinggi ditunjukkan dengan pembangkitan daya secara tepat memenuhi kebutuhan beban, dan tidak akan melanggar batas pembangkitan generator karena teknik RTK yang diusulkan sudah mengantisipasi hal itu yaitu apabila ada kandidat pada iterasi berapun yang berada di luar tempat kedudukan $\mathrm{S}^{0}$ (sebelum iterasi) maka kandidat tersebut dihapus atau dengan kata lain tidak dilibatkan dalam proses iterasi selanjutnya. Sementara pada metoda lain ada beberapa waktu (jam) yang tidak memenuhi Persamaan (3) seperti ditunjukkan pada Tabel 7. Dalam penyelesaian masalah ED, Tabel 7 menunjukkan bahwa pada jam 10, 12, 15, 19, 21 dan jam 22 algoritma JAYA memberikan biaya paling rendah, namun secara total dalam 24 jam teknik RTK memberikan hasil biaya yang terendah dibanding dengan metoda yang lain.

Tabel 7. Perbandingan Hasil Berbagai Metoda dalam Menyelesaikan Masalah ED

\begin{tabular}{|c|c|c|c|c|c|c|c|c|c|c|}
\hline \multirow{2}{*}{ Jam } & \multirow{2}{*}{$\begin{array}{c}\text { Beban } \\
\text { (MW) }\end{array}$} & \multicolumn{2}{|c|}{$\begin{array}{c}\text { Pembangkitan } \\
\text { Daya (MW) }\end{array}$} & \multicolumn{7}{|c|}{ Biaya (USD/Jam) } \\
\cline { 3 - 11 } & G1 & G2 & G3 & GM [1] & ACO [1] & PSO [1] & WOA [1] & JAYA $^{[2]}$ & RTK \\
\hline 1 & 140 & 48 & 40 & 50 & 6297 & 6134 & 6117 & 6113 & 6117,15 & 6112,892 \\
\hline 2 & 150 & 51 & 40 & 50 & 6474 & 6312 & 6292 & 6192 & 6191,99 & 5952,557 \\
\hline 3 & 155 & 56 & 40 & 50 & 6565 & 6439 & 6292 & 6295 & 6291,67 & 6201,660 \\
\hline 4 & 160 & 54 & 41 & 51 & 6650 & 6512 & 6235 & 6228 & 6235,24 & 6227,945 \\
\hline 5 & 165 & 63 & 44 & 50 & 6759 & 6682 & 6544 & 6577 & 6613,53 & 6573,503 \\
\hline 6 & 170 & 64 & 48 & 51 & 6867 & 6807 & 6737 & 6742 & 6779,24 & 6741,178 \\
\hline 7 & 175 & 62 & 42 & 50 & 7209 & 6837 & 6491 & 6489 & 6488,20 & 6488,164 \\
\hline 8 & 180 & 47 & 40 & 50 & 7762 & 6780 & 6093 & 6093 & 6092,93 & 6091,972 \\
\hline 9 & 210 & 65 & 50 & 51 & 8649 & 7457 & 6751 & 6750 & 6758,79 & 6746,326 \\
\hline 10 & 230 & 67 & 52 & 54 & 9713 & 7852 & 6923 & 6912 & 6887,27 & 6907,602 \\
\hline 11 & 240 & 74 & 68 & 77 & 8722 & 8358 & 8034 & 8052 & 8124,42 & 8026,433 \\
\hline 12 & 250 & 76 & 71 & 80 & 8794 & 8594 & 8150 & 8278 & 8141,70 & 8213,114 \\
\hline 13 & 240 & 70 & 59 & 65 & 9654 & 8146 & 7409 & 7417 & 7445,27 & 7407,493 \\
\hline 14 & 220 & 68 & 57 & 58 & 9013 & 7760 & 7101 & 7224 & 7189,51 & 7169,694 \\
\hline 15 & 200 & 68 & 55 & 59 & 7905 & 7424 & 7133 & 7120 & 7085,43 & 7115,741 \\
\hline 16 & 180 & 64 & 46 & 52 & 7268 & 6943 & 6652 & 6661 & 6633,76 & 6606,077 \\
\hline 17 & 170 & 62 & 44 & 50 & 7276 & 6756 & 6554 & 6561 & 6547,44 & 6546,980 \\
\hline 18 & 185 & 68 & 55 & 57 & 7288 & 7146 & 7117 & 7129 & 7278,14 & 7107,765 \\
\hline 19 & 200 & 71 & 61 & 67 & 7544 & 7538 & 7541 & 7535 & 7220,48 & 7531,405 \\
\hline 20 & 240 & 77 & 75 & 86 & 8567 & 8517 & 8751 & 8530 & 8508,15 & 8508,713 \\
\hline 21 & 225 & 75 & 70 & 79 & 8167 & 8153 & 8404 & 8294 & 8128,87 & 8145,527 \\
\hline 22 & 190 & 69 & 58 & 62 & 7314 & 7316 & 7330 & 7311 & 7297,87 & 7304,474 \\
\hline 23 & 160 & 63 & 46 & 50 & 6674 & 6605 & 6588 & 6594 & 6597,72 & 6593,928 \\
\hline 24 & 145 & 54 & 41 & 50 & 6389 & 6275 & 6261 & 6259 & 6260,71 & 6244,009 \\
\hline
\end{tabular}

Keterangan [1]: Trivedi dkk, 2016, December; [2]: Bhoye dkk, 2016.

Biaya pembangkitan daya antara Teknik RTK dengan JAYA hampir berdekatan, dan dalam total sehari teknik RTK menunjukkan biaya $\$ 350,31$ lebih murah dibanding algoritma JAYA. Namun pembangkitan energi bekerja bukan hanya dalam sehari tetapi dalam jangka panjang dan terus menerus, yang pada akhirnya penggunaan teknik RTK memberikan penghematan yang sangat signifikan. Mengacu pada metoda RTK dalam memecahkan masalah ED dan 
berdasar pembangkitan daya yang dihasilkan setiap jam pada kondisi optimal, maka dihitung biaya EED menggunakan Persamaan (9) dan hasilnya dibandingkan dengan metoda lain, seperti ditunjukkan pada Tabel 8. Pada penyelesaian masalah EED, terlihat bahwa teknik RTK memberikan biaya terendah baik bila ditinjau setiap jam maupun secara total dalam 24 jam. Seperti halnya hasil simulasi ED pada Tabel 7, maka hasil simulasi EED untuk teknik RTK juga mendekati algoritma JAYA, dimana dalam sehari teknik RTK menunjukkan biaya $\$ 9558,98$ lebih rendah dibanding JAYA. Namun, untuk operasi pembangkit energi yang terus menerus dan jangka panjang, pada akhirnya teknik RTK memberikan penghematan yang sangat besar.

Tabel 8. Perbandingan Hasil Berbagai Metoda dalam Menyelesaiakan Masalah EED

\begin{tabular}{|c|c|c|c|c|c|c|c|c|c|c|}
\hline \multirow[t]{2}{*}{ Jam } & \multirow{2}{*}{$\begin{array}{l}\text { Beban } \\
\text { (MW) }\end{array}$} & \multicolumn{3}{|c|}{$\begin{array}{c}\text { Pembangkitan } \\
\text { Daya (MW) }\end{array}$} & \multicolumn{6}{|c|}{ Biaya (\$/Jam) } \\
\hline & & G1 & G2 & G3 & $\mathbf{G M}^{[1]}$ & ACO [1] & PSO [1] & WOA $^{[1]}$ & JAYA [2] & RTK \\
\hline 1 & 140 & 48 & 40 & 50 & 8529 & 7250 & 7153 & 7120 & 7152,77 & 6912,060 \\
\hline 2 & 150 & 51 & 40 & 50 & 8648 & 7511 & 7203 & 7186 & 7202,86 & 6572,961 \\
\hline 3 & 155 & 56 & 40 & 50 & 8675 & 7704 & 7278 & 7282 & 7278,12 & 6796,890 \\
\hline 4 & 160 & 54 & 41 & 51 & 8795 & 7742 & 7234 & 7233 & 7234,33 & 7024,942 \\
\hline 5 & 165 & 63 & 44 & 50 & 8758 & 8211 & 7516 & 7545 & 7585,86 & 7151,303 \\
\hline 6 & 170 & 64 & 48 & 51 & 8848 & 8459 & 7729 & 7737 & 7766,53 & 7319,310 \\
\hline 7 & 175 & 62 & 42 & 50 & 8964 & 8406 & 7457 & 7455 & 7458,06 & 7067,844 \\
\hline 8 & 180 & 47 & 40 & 50 & 9308 & 7923 & 7138 & 7138 & 7137,76 & 6771,869 \\
\hline 9 & 210 & 65 & 50 & 51 & 9609 & 9040 & 7745 & 7665 & 7737,85 & 7324,215 \\
\hline 10 & 230 & 67 & 52 & 54 & 10049 & 9599 & 7920 & 7947 & 7890,90 & 7641,698 \\
\hline 11 & 240 & 74 & 68 & 77 & 11520 & 11184 & 9240 & 9337 & 9380,79 & 8751,528 \\
\hline 12 & 250 & 76 & 71 & 80 & 12098 & 11616 & 9386 & 9335 & 9381,83 & 9005,250 \\
\hline 13 & 240 & 70 & 59 & 65 & 10676 & 10320 & 8483 & 8496 & 8525,94 & 8048,690 \\
\hline 14 & 220 & 68 & 57 & 58 & 9982 & 9707 & 8124 & 8014 & 8225,76 & 7803,501 \\
\hline 15 & 200 & 68 & 55 & 59 & 9569 & 9351 & 8195 & 8378 & 8110,22 & 7873,742 \\
\hline 16 & 180 & 64 & 46 & 52 & 9030 & 8469 & 7633 & 7638 & 7605,32 & 7186,039 \\
\hline 17 & 170 & 62 & 44 & 50 & 8872 & 8189 & 7525 & 7528 & 7521,11 & 7167,122 \\
\hline 18 & 185 & 68 & 55 & 57 & 9273 & 9061 & 8146 & 8156 & 8341,13 & 7710,774 \\
\hline 19 & 200 & 71 & 61 & 67 & 9990 & 9852 & 8639 & 8665 & 8303,99 & 8247,883 \\
\hline 20 & 240 & 77 & 75 & 86 & 12646 & 11897 & 10353 & 10112 & 9850,03 & 9319,297 \\
\hline 21 & 225 & 75 & 70 & 79 & 11496 & 11101 & 9710 & 9625 & 9364,58 & 8928,892 \\
\hline 22 & 190 & 69 & 58 & 62 & 9534 & 9488 & 8390 & 8430 & 8349,91 & 8008,535 \\
\hline 23 & 160 & 63 & 46 & 50 & 8667 & 8077 & 7846 & 7590 & 7568,56 & 7187,706 \\
\hline 24 & 145 & 54 & 41 & 50 & 8517 & 7498 & 7254 & 7252 & 7253,71 & 6846,873 \\
\hline
\end{tabular}

Keterangan [1]: Trivedi dkk, 2016, December; [2]: Bhoye dkk, 2016.

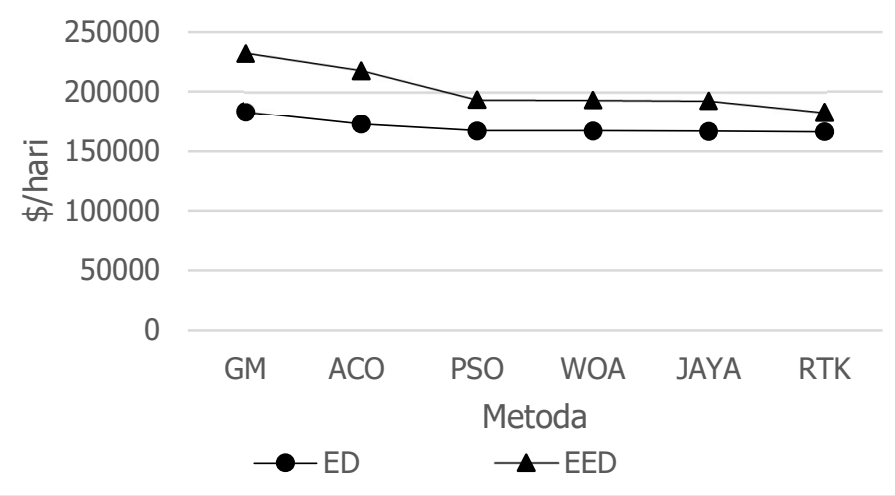

Gambar 3. Perbandingan Biaya ED dan CEED dari Berbagai Metoda 
Biaya total untuk ED dan CEED dalam 24 jam untuk berbagai metoda ditunjukkan pada Gambar 3. Sedangkan Gambar 4 menunjukkan penghematan biaya yang didapat dengan menggunakan teknik RTK dibandingkan dengan metoda yang lainnya.

Pada Gambar 3, pada teknik RTK terlihat bahwa biaya optimal pada ED sebesar $\$ 166565,152$, sedangkan bila mempertimbangan emisi (CEED) maka biaya optimalnya sebesar $\$ 182668,924$. Ada perbedaan sebesar $9,67 \%$ antara ED dan CEED. Ini mengisyaratkan bahwa dengan mempertimbangkan emisi di dalam pemenuhan permintaan beban maka biaya optimasinya lebih besar 9,67\% dibanding tanpa mempertimbangkan emisi. Sedangkan untuk hal yang sama pada metoda GM (26,45\%), ACO (25,56\%), PSO (15,40\%), WOA (15,24\%), dan Jaya Algorithm (15,16\%). Dari sini terlihat bahwa teknik RTK memiliki selisih biaya antara ED dan CEED paling kecil (yaitu sebesar 9,67\%) dibandingkan dengan metoda lainnya yang digunakan sebagai pembanding di dalam makalah ini.

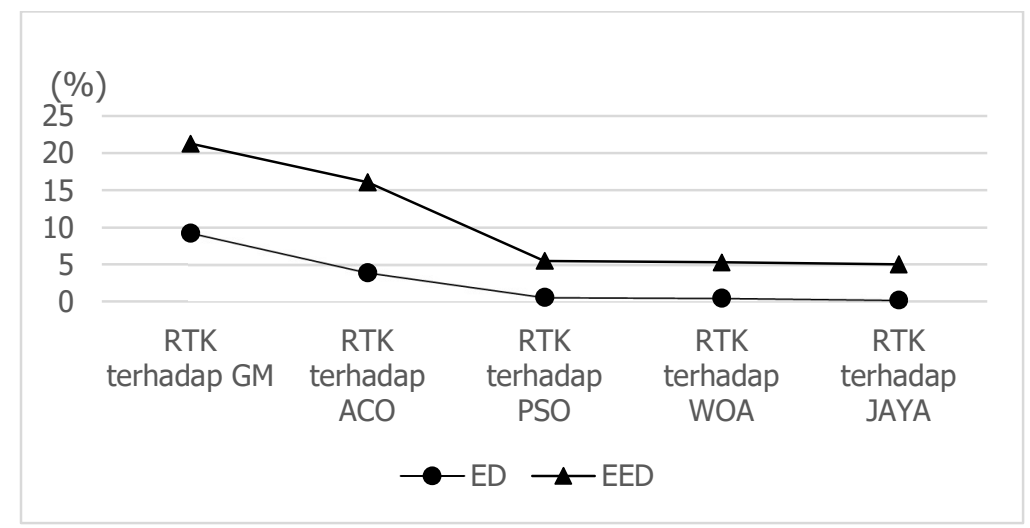

Gambar 4. Penghematan Biaya dari Teknik RTK Terhadap Metoda Pembanding

Penghematan biaya bahan bakar pembangkit energi (tanpa mempertimbangkan emisi) yang didapat dari penggunaan teknik RTK terhadap metoda GM, ACO, PSO, WOA dan JAYA masingmasing sebesar $9,24 \%, 3,91 \%, 0,56 \%, 0,47 \%$ dan 0,21\%. Sedangkan dalam penyelesaian CEED (optimasi kombinasi biaya bahan bakar dan emisi pembangkit energi), teknik RTK memiliki penghematan terhadap GM, ACO, PSO, WOA dan JAYA masing-masing sebesar $21,28 \%, 16,09 \%, 5,52 \%, 5,31 \%$ dan 5,04\%. Sementara itu dengan mempertimbangkan emisi maka biaya yang timbul pada teknik RTK sebesar $9,67 \%$ dibanding tanpa mempertimbangkan emisi, sedangkan untuk metoda lain lebih tinggi lagi. Hal ini menunjukkan bahwa teknik RTK memiliki keunggulan dibanding metoda pembandingnya baik dalam menyelesaikan ED maupun CEED.

\section{KESIMPULAN}

Metode optimasi berdasarkan teknik reduksi tempat kedudukan kandidat untuk menyelesaikan masalah ED dan CEED telah diusulkan dalam makalah ini. Teknik ini sederhana yaitu mencari kandidat terbaik dari setiap tempat kedudukan yang direduksi. Di dalam mereduksi tempat kedudukan harus dipastikan bahwa kandidat terbaik sebelumnya berada di dalam tempat kedudukan yang telah direduksi. Apabila ada kandidat yang berada di luar tempat kedudukan awal, maka kandidat tersebut tidak diikutkan dalam proses iterasi berikutnya karena kandidat tersebut melanggar kendala generator. Dari hasil pengujian maka dapat dikemukakan beberapa keunggulan teknik RTK, yaitu antara lain: (i). memiliki cara kerja yang sederhana dalam mencapai titik optimal, karena menggunakan pendekatan dari tempat kedudukan ke 
tempat kedudukan yang lebih kecil (area ke area) bukan pendekatan titik ke titik sebagaimana layaknya metoda artifisial yang lainnya, (ii). tidak akan pernah melanggar batas generator, (iii). Memiliki keakuratan tinggi, yang ditunjukkan dengan daya yang dibangkitkan selalu sama (tepat) dengan permintaan beban, (iv). Memberikan kinerja optimasi lebih baik dibanding metoda lainnya, dengan kata lain teknik RTK memiliki tingkat kepastian tinggi dalam mencapai titik global minimum (titik solusi/optimal), dengan men-set nilai $\varnothing$ yang sangat kecil (sangat tidak signifikan dibanding biaya bahan bakar pembangkitan energi total). Dalam makalah ini $\varnothing$ di-set sebesar 0,5 , angka yang sangat kecil bila dibanding dengan biaya bahan bakar yang berkisar antara 5952,557 hingga 8213,114. Berdasarkan diskusi tersebut maka teknik RTK dapat dipertimbangkan untuk diterapkan dalam penyelesaian optimasi biaya bahan bakar pembangkit energi, baik tanpa mempertimbangkan emisi maupun dengan mempertimbangkan emisi.

\section{DAFTAR RUJUKAN}

Adhirai, S., Mahapatra, R. P., \& Singh, P. (2018). The whale optimization algorithm and its implementation in MATLAB. International Journal of Computer and Information Engineering, 12(10), 815-822.

Apostolopoulos, T., \& Vlachos, A. (2010). Application of the firefly algorithm for solving the economic emissions load dispatch problem. International journal of combinatorics, 2011, 1-23. doi:https://doi.org/10.1155/2011/523806

Bhattacharya, A., \& Chattopadhyay, P. K. (2011). Solving economic emission load dispatch problems using hybrid differential evolution. Applied Soft Computing, 11(2), 25262537. doi:https://doi.org/10.1016/j.asoc.2010.09.008

Bhesdadiya, R. H., Pandya, M. H., Trivedi, I. N., Jangir, N., Jangir, P., \& Kumar, A. (2016). Price penalty factors based approach for combined economic emission dispatch problem solution using Dragonfly Algorithm. International Conference (pp. 436-441). Nagercoil, India: IEEE. doi:https://doi.org/10.1109/ICEETS.2016.7583794

Bhoye, M., Pandya, M. H., Valvi, S., Trivedi, I. N., Jangir, P., \& Parmar, S. A. (2016). An Emission Constraint Environment Dispatch Problem Solution with Microgrid using JAYA Algorithm. International Conference on Energy Efficient Technologies for Sustainability (ICEETS) (pp. 497-502). Nagercoil, India: IEEE. doi:https://doi.org/10.1109/ICEETS.2016.7583805

Dey, B., Roy, S. K., \& Bhattacharyya, B. (2019). Solving multi-objective economic emission dispatch of a renewable integrated microgrid using latest bio-inspired algorithms. Engineering Science and Technology. an International Journal, 22(1), 55-66. doi:https://doi.org/10.1016/j.jestch.2018.10.001

Dhifaoui, C., Marouani, I., \& Abdallah, H. H. (2020). MOALO Algorithm applied to Dynamic Economic Environmental Dispatch including renewable energy. IJCSNS, 20(6), 36-47. 
Faseela, C. K., \& Vennila, H. (2018). Economic and Emission Dispatch using Whale Optimization Algorithm (WOA). International Journal of Electrical and Computer Engineering, 8(3), pp. 1297-1304. doi:https://doi.org/10.11591/ijece.v8i3

Gonidakis, D., \& Vlachos, A. (2015). Bat algorithm approaches for solving the combined economic and emission dispatch problem. International Journal of Computer Applications, 124(1), 1-7. doi:https://doi.org/10.5120/ijca2015905288.

Güvenç, U., Sönmez, Y. U., Duman, S., \& Yörükeren, N. (2012). Combined economic and emission dispatch solution using gravitational search algorithm. Scientia Iranica, 196), 1754-1762. doi:https://doi.org/10.1016/j.scient.2012.02.030

Hardiansyah, Junaidi, \& Yandri. (2016). Combined Economic Emission Dispatch Solution Using Simulated Annealing Algorithm. IOSR Journal of Electrical and Electronics Engineering, 11(5), 141-148. doi:https://doi.org/10.9790/1676-110502141148

Jiang, S., Zhang, C., Wu, W., \& Chen, S. (2019). Combined economic and emission dispatch problem of wind-thermal power system using gravitational particle swarm optimization algorithm. Mathematical Problems in Engineering, 2019, 1-19. doi:https://doi.org/10.1155/2019/5679361

Kar, S. R., Dash, P. D., \& Sanyal, S. K. (2019). Application of Whale Optimization Algorithm for Environment Constrained Economic Dispatch of Fixed Head Hydro-Wind-Thermal Power System. International Journal of Engineering and Advanced Technology, 9(1), 5608-5616. doi:https://doi.org/10.35940/ijeat.A2261.109119

Li, M., Du, W., \& Nian, F. (2014). An Adaptive Particle Swarm Optimization Algorithm Based on Directed Wighted Complex Network. Mathematical Problems in Engineering, 1-7. doi:http://dx.doi.org/10.1155/2014/434972

Maydilasari, M. P., Zuliari, E. A., \& Wati, T. (2020). Economic Emission Dispatch Mempertimbangkan Valve-Point Effect Menggunakan Particle Swarm Optimization (PSO). Prosiding Seminar Nasional Sains dan Teknologi Terapan (pp. 1). Surabaya: Institut Teknologi Adhi Tama.

Rao, R. (2016). Jaya: A simple and new optimization algorithm for solving constrained and unconstrained optimization problems. International Journal of Industrial Engineering Computations, 71 1), 19-34. doi:https://doi.org/10.5267/j.jijec.2015.8.004

Ryu, H. S., \& Kim, M. K. (2020). Combined Economic Emission Dispatch with EnvironmentBased Demand Response Using WU-ABC Algorithm. Energies, 13(23), 6450. doi:https://doi.org/10.3390/en13236450 
Trivedi, I. N., Bhoye, M., Bhesdadiya, R. H., Jangir, P., Jangir, N., \& Kumar, A. (2016). An emission constraint environment dispatch problem solution with microgrid using Whale Optimization Algorithm. 2016 National Power Systems Conference (NPSC) (pp. 1-6). Bhubaneswar: IEEE. doi:https://doi.org/10.1109/NPSC.2016.7858899

Wood, A. J., Wollenberg, B. F., \& Sheblé, G. B. (2013). Power generation, Operation, and Control. John Wiley \& Sons. 